Article

\title{
New Approach to Remove Heavy Metals from Wastewater by the Coagulation of Alginate-Rhamnolipid Solution with Aluminum Sulfate
}

\author{
Aleum Lee ${ }^{1}$ and Kyoungrean Kim ${ }^{2,3, *}$ \\ 1 Department of Civil and Environmental Engineering, Seoul National University, Seoul 08826, Korea; \\ aleum.lee@snu.ac.kr \\ 2 Marine Environmental Research Center, Korea Institute of Ocean Science and Technology, \\ Busan 49111, Korea \\ 3 Ocean Science, KIOST School, University of Science and Technology, Busan 49111, Korea \\ * Correspondence: kyoungrean@kiost.ac.kr
}

Received: 26 October 2020; Accepted: 30 November 2020; Published: 3 December 2020

check for updates

\begin{abstract}
This study was conducted using alginate-rhamnolipid (Alg-Rh) solutions on copper ions $\left(\mathrm{Cu}^{2+}\right)$ as an application of coagulation with aluminum sulfate $\left(\mathrm{Al}_{2}\left(\mathrm{SO}_{4}\right)_{3}\right)$. The results show that solid phases were rapidly formed as an output of the reaction between $\mathrm{Alg}-\mathrm{Rh}$ and $\mathrm{Al}_{2}\left(\mathrm{SO}_{4}\right)_{3}$. It could be considered that the $\mathrm{Al}_{2}\left(\mathrm{SO}_{4}\right)_{3}$ concentration and the existence of $\mathrm{Cu}^{2+}$ have an impact on forming hard coagulation, in that the total volume has been increased with increasing $\mathrm{Al}_{2}\left(\mathrm{SO}_{4}\right)_{3}$ and the existence of $\mathrm{Cu}^{2+}$. The number of ions of aluminum $\left(\mathrm{Al}^{3+}\right)$ and sulfate $\left(\mathrm{SO}_{4}{ }^{2-}\right)$ were also increased with $\mathrm{Al}_{2}\left(\mathrm{SO}_{4}\right)_{3}$. The efficiency of $\mathrm{Cu}^{2+}$ removal was constant above $75.0 \%$, hence the average value was $76.8 \%$.
\end{abstract}

Keywords: heavy metals; remediation; rhamnolipid; alginate; coagulation

\section{Introduction}

Water is one of the most important resources in the world. It is already known that $71 \%$ of the Earth's surface is covered with water and only $2.5 \%$ of it is freshwater [1]. Nowadays, seawater has been found to be converted to freshwater, but freshwater is still an important resource for living organisms, including humans [2,3]. Despite such an important resource, water pollution has been induced by a variety of contaminants, such as heavy metals and organic pollutants [4-7]. In particular, the pollution by heavy metals has been increasing with the development of industry, and it has already been proved that a high concentration of heavy metals has a dangerous impact on living organisms and the environment as hazardous materials [8-10]. It can be accumulated in living organisms and inhibit their metabolism to the point of death [11,12]. Accordingly, water treatment has been essentially required, in that water quality should be improved for water resource recirculation in conditions of limited water resources. Moreover, the treatment of wastewater that contains solid material should include a separation process. Recently, various wastewater treatment technologies have been developed using biological, chemical, and physical methods but we have yet to develop high-efficiency remediation technology [13-15].

Alginate has been mainly used to form a capsulated medicine as a raw material to be connected with divalent ions for its special property [16]. This novel property makes it possible for various applications such as coagulation to remove heavy metals [17]. Rhamnololipids, a biosurfactant, also have proved their novel property to remediate heavy metals [18-21]. Both materials are bio-derived 
and have relatively long chains [22,23]. Their combined properties and longer molecular chain would be expected to improve the efficiency of solid/liquid separation and heavy metal removal.

In view of the above, Alg-Rh complexes would form a longer chain than a simple alginate or rhamnolipid molecule. This molecular structure can coagulate with heavy metals as a long polymer by connecting together. Heavy metals are usually divalent ions or trivalent ions, and they are substituted with more than two sodium ions of sodium alginate to form a relatively round shape. Moreover, adding aluminum ions makes it more aggregated as supporting strong flocculation. The solid phase would form only one mass, and the mass does not tend to be fluid. Therefore, it would be much easier to separate the solid phase with a liquid phase.

Herein, we would like to suggest the possibility of using Alg-Rh complexes as a green coagulant for heavy metals and improve their efficiency for solid and liquid separation. Moreover, the water removing heavy metals would be investigated for characterization as a preliminary study.

\section{Materials and Methods}

\subsection{Materials}

Sodium alginate was supplied by Junsei Chemical Co., Ltd. (Tokyo, Japan), and the rhamnolipids (R90-100G) were purchased from AGAE Technologies (Corvallis, Oregon, USA). Additionally, copper standards (Kanto Chemical Co., Inc., Tokyo, Japan) were adjusted to make a $100 \mathrm{mg} / \mathrm{L}$ copper solution. A small amount of nitric acid (504-756 mg/L) is contained in the standard solution (980-1020 mg/L). Aluminum sulfate from Kanto Chemical Co., Inc., Tokyo, Japan, was also used as a coagulant.

\subsection{Experimental Methods}

Alginate solution $(4 \% w / v)$ was mixed with a rhamanolipid solution $(0.1 \% w / v)$ at $80{ }^{\circ} \mathrm{C}$ for $2 \mathrm{~h}$, and then a copper standards solution was put into the mixture (Figure 1) [24-27]. A small amount of copper standard solution, $5 \mathrm{~mL}$ of $100 \mathrm{mg} / \mathrm{L}$, was adopted for this preliminary study. To identify the effects of heavy metal in the mixture, samples have been also made without $\mathrm{Cu}^{2+}$. Aluminum sulfate $\left(\mathrm{Al}_{2}\left(\mathrm{SO}_{4}\right)_{3}\right)$ solution at $0.1 \%, 0.3 \%$, and $0.5 \% w / v$ of total volume was added as an additive to support coagulation. All the experiments for coagulation were conducted in $250 \mathrm{~mL}$ glass beakers. Then, a mass wrapped in a thin layer was formed and the liquid phase (water) was separated from the solid phase by gravity. The final step in this experiment is filtering the water using a $0.45 \mu \mathrm{m}$ acrylic-based filter.
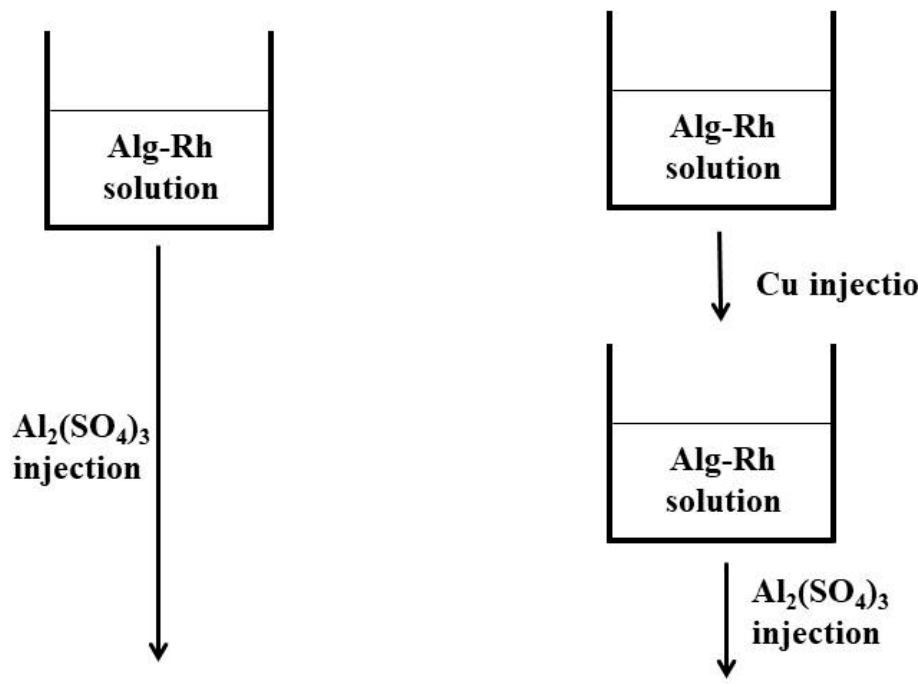

Figure 1. Cont. 


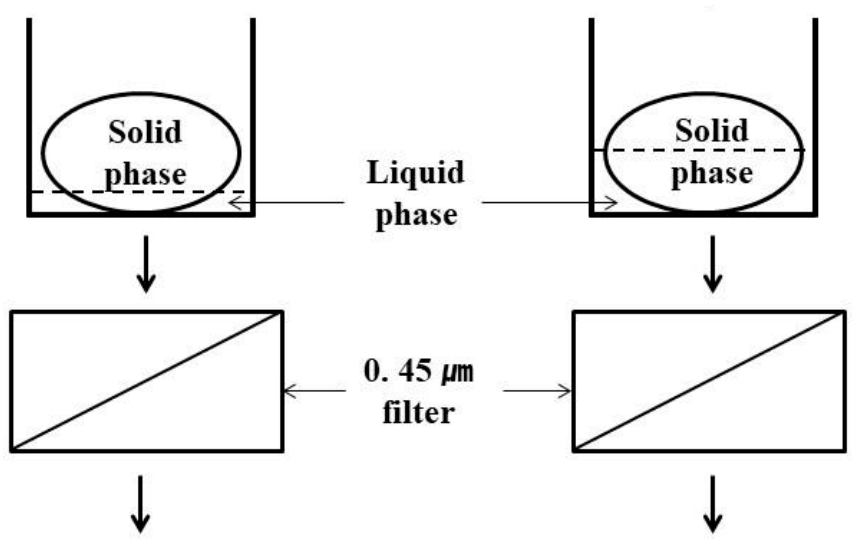

Figure 1. Schematic diagram of the experimental flow.

\subsection{Analysis}

After the reaction, the samples were analyzed using ion chromatography (Dionex ${ }^{\mathrm{TM}}$ Aquion $^{\mathrm{TM}}$ Ion Chromatography (IC) System, Thermo Fisher scientific, Waltham, MA, USA) to investigate the sulfate ions. An inductively coupled plasma optical emission spectrometer (ICP/OES) (Optima 7300DV, Perkin Elmer, Waltham, MA, USA) was also used for $\mathrm{Cu}^{2+}$ and $\mathrm{Al}^{3+}$. The total organic carbon (TOC) was determined using a UV-vis spectrophotometer (DR-5000, Hach, Loveland, CO, USA), followed by US EPA (United States Environmental Protection Agency) methods (method 10129).

\section{Results and Discussion}

\subsection{Characterization of the Purified Water}

Several distinct characteristics of the purified water will be discussed in detail. As explained above, the water has been separated from the formed mass, the solid phase, by gravity. The mass shows a different degree of rigidity with different concentrations of the coagulant (Figure 2). The pressure generated in the separation process causes the formed mass to break and the liquid contents wrapped in a thin layer to flow out. Eventually, the separation process could no longer proceed. In the case of the busted sample, the obtained water contained lots of organic matter and heavy metals that flowed out from the mass. Therefore, the samples were excluded from the exact analysis. Figure $2 \mathrm{a}$ shows that the liquid in the mass spilled into the water because of the weak bond of the mass surface. The sample without $\mathrm{Cu}^{2+}$ was observed to be busted easily compared to the other samples. The sample with $0.1 \%$ $\mathrm{Al}_{2}\left(\mathrm{SO}_{4}\right)_{3}$ and $\mathrm{Cu}^{2+}$ made two separated phases which are not distinguishable in macroscopic view. However, the sticky liquid wrapped in the thin layer has been discovered to be separated (Figure 2b). In the case of Figure 2c, a remarkable change in the solid phase has been shown. The liquid in the mass has a sticky property because of the alginate and it makes lots of small bubbles inside the layer. The liquid has not been observed to be spilled to the water. The samples with $0.3 \%$ and $0.5 \% \mathrm{Al}_{2}\left(\mathrm{SO}_{4}\right)_{3}$ solution are comparatively hard (Figure 2d). The image was taken in tilted form for a more distinctive change from the others. The separated water was observed to be very transparent.

Figure 3 shows the different volume of the liquid phase depending on samples which have different $\mathrm{Cu}^{2+}$ and $\mathrm{Al}_{2}\left(\mathrm{SO}_{4}\right)_{3}$ concentrations. The sample without $\mathrm{Cu}^{2+}$ shows the smallest total volume because it is difficult to separate the water without bursting the mass. The total volume of the samples with $\mathrm{Cu}^{2+}$ has been increased with increasing $\mathrm{Al}_{2}\left(\mathrm{SO}_{4}\right)_{3}$, and the obtained volume remained stable from $0.2 \% \mathrm{Al}_{2}\left(\mathrm{SO}_{4}\right)_{3}$ sample. It would be considered that $\mathrm{Cu}^{2+}$ also has an impact on coagulation behavior. Divalent ions have already proved their property to substitute two sodium ions in alginate since they have been discovered [28]. 


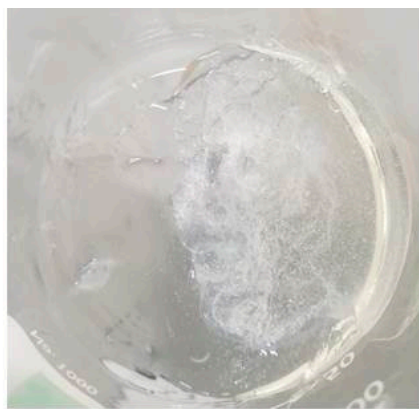

(a)

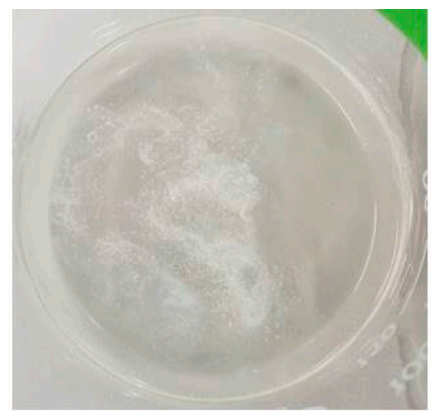

(b)

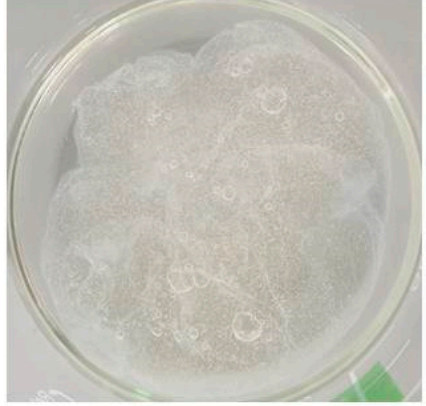

(c)

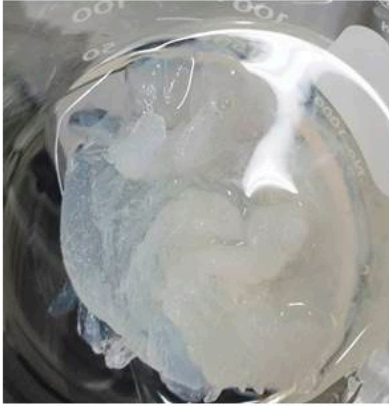

(d)

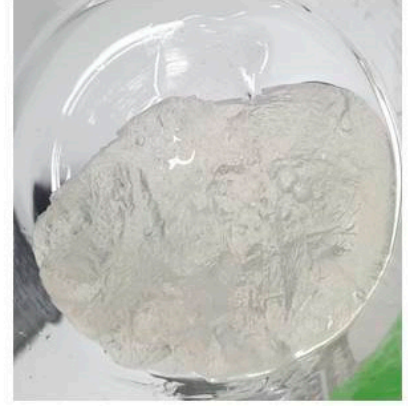

(e)

Figure 2. The difference depending on the $\mathrm{Cu}^{2+}$ and $\mathrm{Al}_{2}\left(\mathrm{SO}_{4}\right)_{3}$ concentrations $\left((\mathbf{a}) 0.1 \%\left(\mathrm{Al}_{2}\left(\mathrm{SO}_{4}\right)_{3}\right)\right.$ without $\mathrm{Cu}^{2+}$, (b) $0.1 \% \mathrm{Al}_{2}\left(\mathrm{SO}_{4}\right)_{3}$ with $\mathrm{Cu}^{2+}$, (c) $0.3 \% \mathrm{Al}_{2}\left(\mathrm{SO}_{4}\right)_{3}$ with $\mathrm{Cu}^{2+}$, (d) $0.5 \% \mathrm{Al}_{2}\left(\mathrm{SO}_{4}\right)_{3}$ with $\mathrm{Cu}^{2+},(\mathbf{e})$ the solid phase after separation).

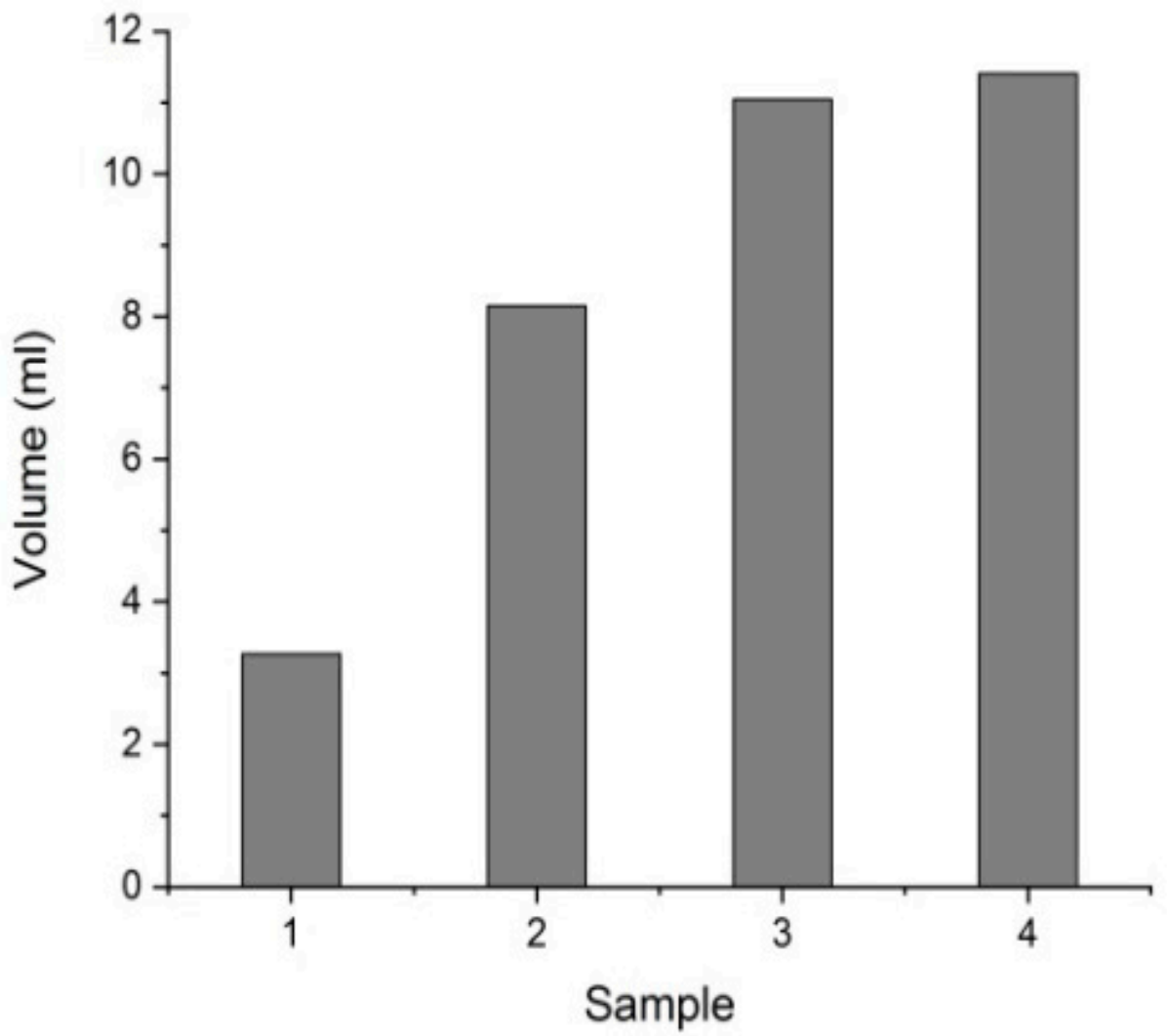

Figure 3. Total volume obtained from experiments in this research $\left(1: 0.1 \%\left(\mathrm{Al}_{2}\left(\mathrm{SO}_{4}\right)_{3}\right)\right.$ with $\mathrm{Cu}^{2+}, 2$ : $0.1 \%\left(\mathrm{Al}_{2}\left(\mathrm{SO}_{4}\right)_{3}\right)$ with $\mathrm{Cu}^{2+}, 3: 0.3 \%\left(\mathrm{Al}_{2}\left(\mathrm{SO}_{4}\right)_{3}\right)$ with $\mathrm{Cu}^{2+}, 4$ : the solid phase after separation). 
TOC contents are also distinctive features in this experiment. Alginate and rhamnolipids have many carbons on their own, so it can be an important indicator of the remediation degree of the Alg-Rh complexes. As shown in Table 1, the highest TOC contents were observed in sample 1. The results indicate that $\mathrm{Cu}^{2+}$ works as another coagulant with $\mathrm{Al}_{2}\left(\mathrm{SO}_{4}\right)_{3}$. The bond of $\mathrm{Al}^{3+}$ or $\mathrm{Cu}^{2+}$ with alginate has been proved [29-31]. As $\mathrm{Al}^{3+}$ and $\mathrm{Cu}^{2+}$ ions gather the alginate and rhamnolipid more tightly, carbon would not be spilled out of the mass to liquid phase.

Table 1. Characteristics of the liquid phase separated from the mixed phase with solid.

\begin{tabular}{ccc}
\hline Sample Number & TOC $(\mathbf{m g} / \mathbf{L})$ & SO $_{4}{ }^{2-}(\mathbf{g} / \mathrm{L})$ \\
\hline Sample 1 & $116.3( \pm 5.3)$ & $2.244( \pm 0.190)$ \\
Sample 2 & $32.00( \pm 2.5)$ & $1.573( \pm 0.078)$ \\
Sample 3 & $15.50( \pm 4.4)$ & $5.340( \pm 0.184)$ \\
Sample 4 & $14.17( \pm 2.0)$ & $8.976( \pm 0.734)$
\end{tabular}

Sample 1: $0.1 \% \mathrm{Al}_{2}\left(\mathrm{SO}_{4}\right)_{3}$ without $\mathrm{Cu}^{2+}$, Sample 2: $0.1 \% \mathrm{Al}_{2}\left(\mathrm{SO}_{4}\right)_{3}$ with $\mathrm{Cu}^{2+}$, Sample 3: $0.3 \% \mathrm{Al}_{2}\left(\mathrm{SO}_{4}\right)_{3}$ with $\mathrm{Cu}^{2+}$, Sample 4: $0.5 \% \mathrm{Al}_{2}\left(\mathrm{SO}_{4}\right)_{3}$ with $\mathrm{Cu}^{2+}$.

The concentration of sulfate ions $\left(\mathrm{SO}_{4}{ }^{2-}\right)$ has been detected as a dominant material. The existence of $\mathrm{Cu}^{2+}$ played an important role, in that the $\mathrm{SO}_{4}{ }^{2-}$ concentration in sample 1 was 1.43 times higher. This indicates that $\mathrm{Cu}^{2+}$, the only controlled factor, is an important substance to support coagulation. The higher effects would be expected with higher contents of heavy metals inside the Alg-Rh solution. Not only $\mathrm{Cu}^{2+}$ but also other heavy metals with a strong ionic strength could be applied to this study. Except for sample 1, this is an increasing tendency among the samples. In comparison with sample 2, sample 3 and 4 have 3.39 and 5.71 times higher in $\mathrm{SO}_{4}{ }^{2-}$ concentrations. Higher $\mathrm{Al}_{2}\left(\mathrm{SO}_{4}\right)_{3}$ shows higher sulfate ions. We can assume that $\mathrm{Al}^{3+}$ would react more extremely at higher $\mathrm{Al}_{2}\left(\mathrm{SO}_{4}\right)_{3}$ contents, suggesting a higher efficiency.

\subsection{Respective Correlation}

As explained above, the Alg-Rh solution has high contents of carbon, and the contents are closely related to the reaction with $\mathrm{Al}_{2}\left(\mathrm{SO}_{4}\right)_{3}$. Therefore, the contents of $\mathrm{Al}^{3+}, \mathrm{SO}_{4}{ }^{2-}$, and $\mathrm{Cu}^{2+}$ in the water are also expected to have a correlation with TOC as the result of the reaction. As shown in Figure 4, the sulfate ions have been increased with increasing $\mathrm{Al}_{2}\left(\mathrm{SO}_{4}\right)_{3}$. This does not seem to have a correlation with TOC without $\mathrm{Cu}^{2+}$, in that there is not a dramatic change comparing the significant change in TOC between sample 1 and 2. With $\mathrm{Cu}^{2+}$, the concentrations have been increased in multiples, as explained above, not showing a specific relation with TOC. Indeed, the TOC contents of sample 2 and 3 decreased 0.48 and 0.44 times compared to sample 1 , contrary to the constantly increased $\mathrm{SO}_{4}{ }^{2-}$.

$\mathrm{Al}^{3+}$ concentrations also have been constantly increased similar to $\mathrm{SO}_{4}{ }^{2-}$ (Figure 5). A difference is that $\mathrm{Al}^{3+}$ was used to form coagulation as an effective coagulant, so the contents are definitely lower than those of $\mathrm{SO}_{4}{ }^{2-}$. The concentrations are respectively remarked at $0.360,0.236,0.854$, and $1.400 \mathrm{~g} / \mathrm{L}$. Compared to sample 1, more $\mathrm{Al}^{3+}$ in sample 2 is expected to react with the Alg-Rh solutions, detecting a lower $\mathrm{Al}^{3+}$ in sample 2 . 


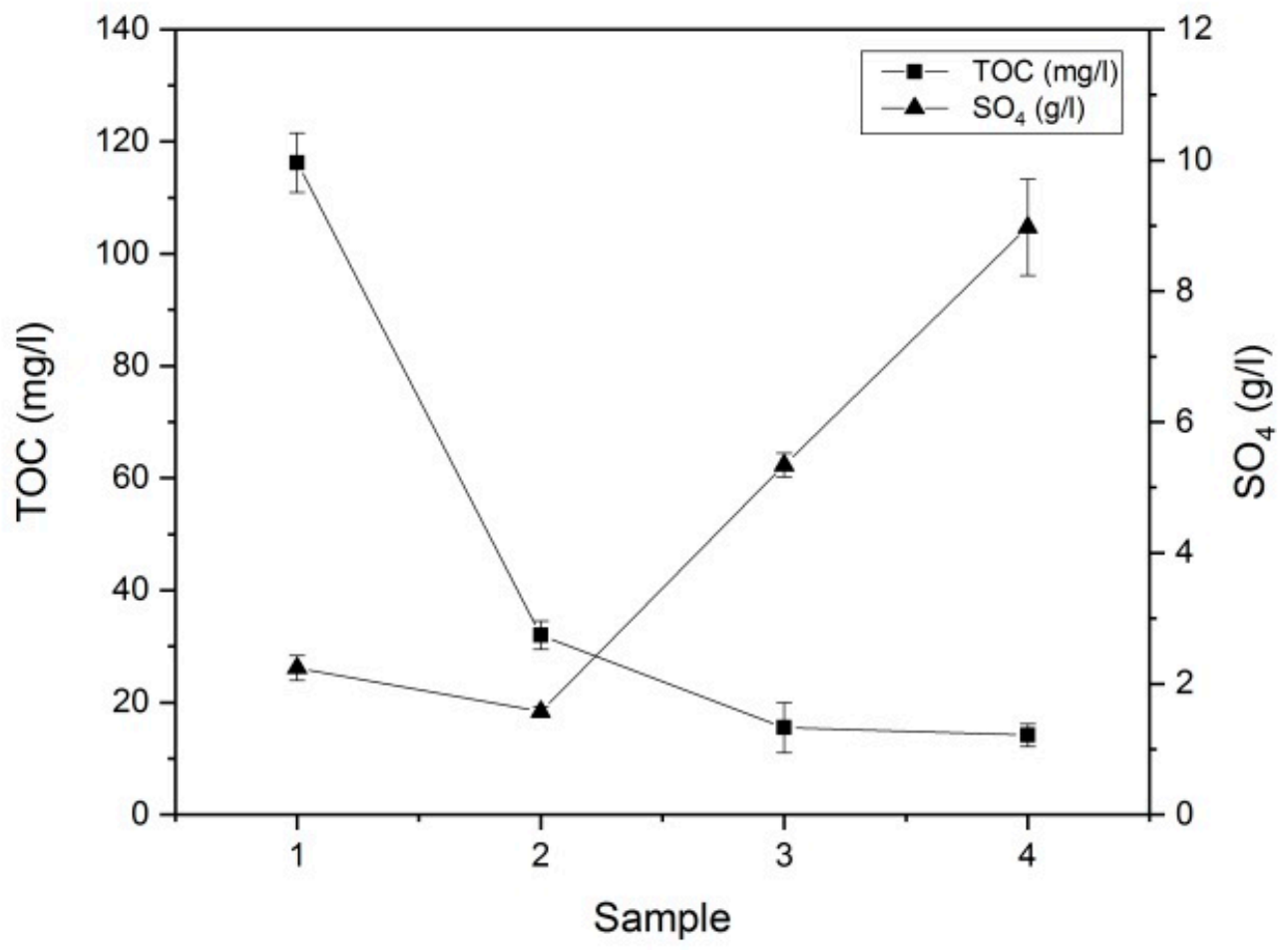

Figure 4. Variation in TOC and $\mathrm{SO}_{4}{ }^{2-}$ depending on samples (Sample 1: $0.1 \% \mathrm{Al}_{2}\left(\mathrm{SO}_{4}\right)_{3}$ without $\mathrm{Cu}^{2+}$, Sample 2: $0.1 \% \mathrm{Al}_{2}\left(\mathrm{SO}_{4}\right)_{3}$ with $\mathrm{Cu}^{2+}$, Sample 3: $0.3 \% \mathrm{Al}_{2}\left(\mathrm{SO}_{4}\right)_{3}$ with $\mathrm{Cu}^{2+}$, Sample $4: 0.5 \% \mathrm{Al}_{2}\left(\mathrm{SO}_{4}\right)_{3}$ with $\mathrm{Cu}^{2+}$ ).

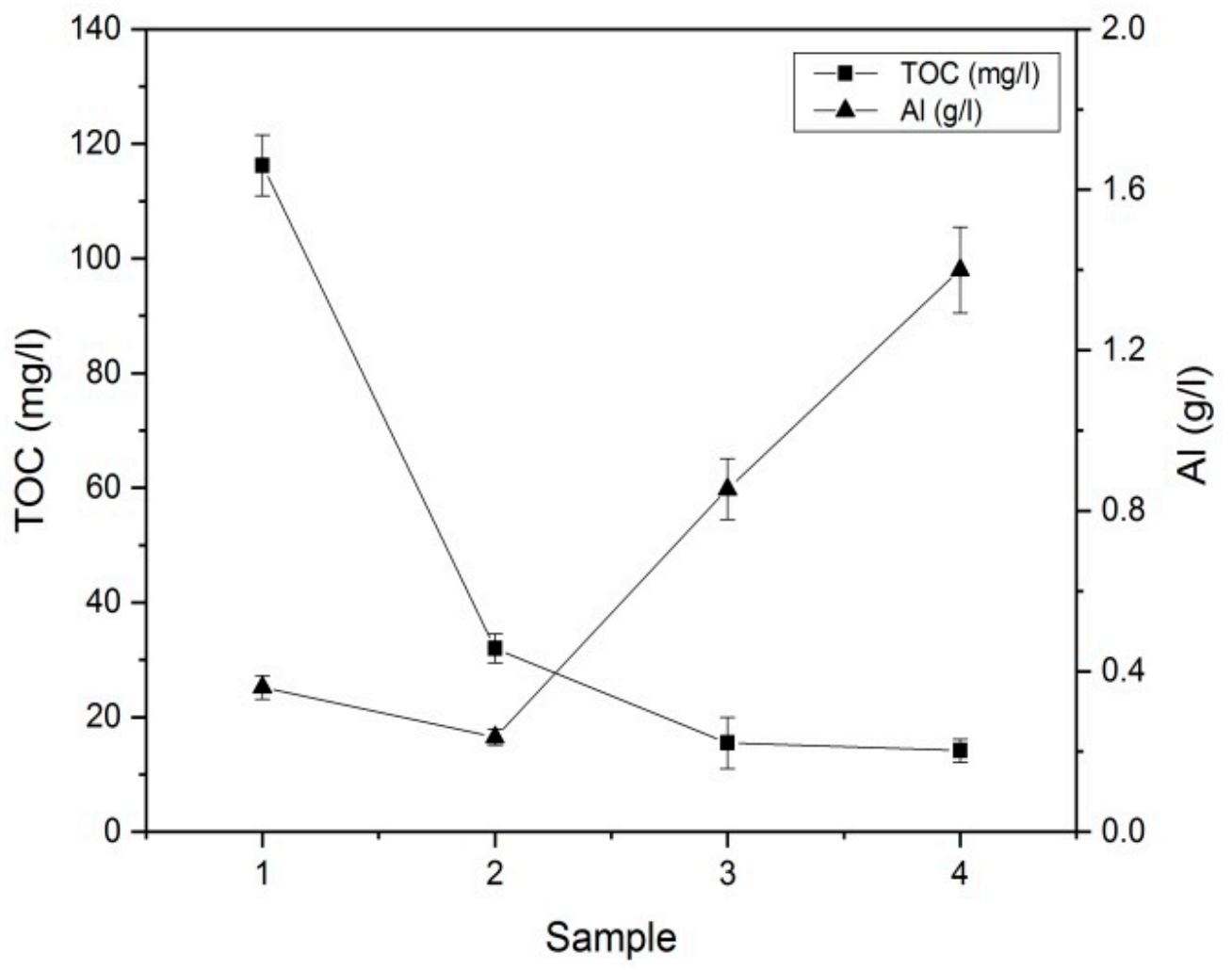

Figure 5. Change in the TOC and $\mathrm{Al}^{3+}$ depending on sample (Sample 1: $0.1 \%\left(\mathrm{Al}_{2}\left(\mathrm{SO}_{4}\right)_{3}\right)$ without $\mathrm{Cu}^{2+}$, Sample 2: $0.1 \%\left(\mathrm{Al}_{2}\left(\mathrm{SO}_{4}\right)_{3}\right)$ with $\mathrm{Cu}^{2+}$, Sample 3: $0.3 \%\left(\mathrm{Al}_{2}\left(\mathrm{SO}_{4}\right)_{3}\right)$ with $\mathrm{Cu}^{2+}$, Sample 4: $0.5 \%$ $\left(\mathrm{Al}_{2}\left(\mathrm{SO}_{4}\right)_{3}\right)$ with $\left.\mathrm{Cu}^{2+}\right)$. 
Figure 6 shows the $\mathrm{Cu}^{2+}$ concentrations with a change in $\mathrm{Al}_{2}\left(\mathrm{SO}_{4}\right)_{3}$. This is not remarked at sample 1 because $\mathrm{Cu}^{2+}$ was not put into sample 1. They are remarked at $23.150( \pm 1.485), 26.850$ $( \pm 2.616)$, and $23.500( \pm 0.281)$ with sample 2,3 , and $4 . \mathrm{Cu}^{2+}$ in samples 2 and 4 are quite similar, but sample 2 has more or less high value compared to them. The standard deviation of sample 2 is high. This indicates that there is a possibility to get a similar value with sample 2 and 4 during repeated experiments. However, the values show quite constant values, even though the TOC contents were decreased. Therefore, it is considered that $\mathrm{Cu}^{2+}$ has an effect on improving the efficiency to coagulate the solution with $\mathrm{Al}^{3+}$, but the $\mathrm{Al}_{2}\left(\mathrm{SO}_{4}\right)_{3}$ and TOC contents do not affect the $\mathrm{Cu}^{2+}$ removal. There would be high potential to remove not only copper but also other di- and trivalent ions. this indicates that a bridging effect would be expected using heavy metals as a bridge and then it results in heavy metal removal. Moreover, as shown, $\mathrm{Al}^{3+}$ has a large effect on the $\mathrm{Cu}^{2+}$ removal. With these results, other heavy metals in wastewater may successfully replace the role of $\mathrm{Al}^{3+}$. Therefore, it could be suggested that a variety of heavy metals in wastewater can be also removed at the same time.

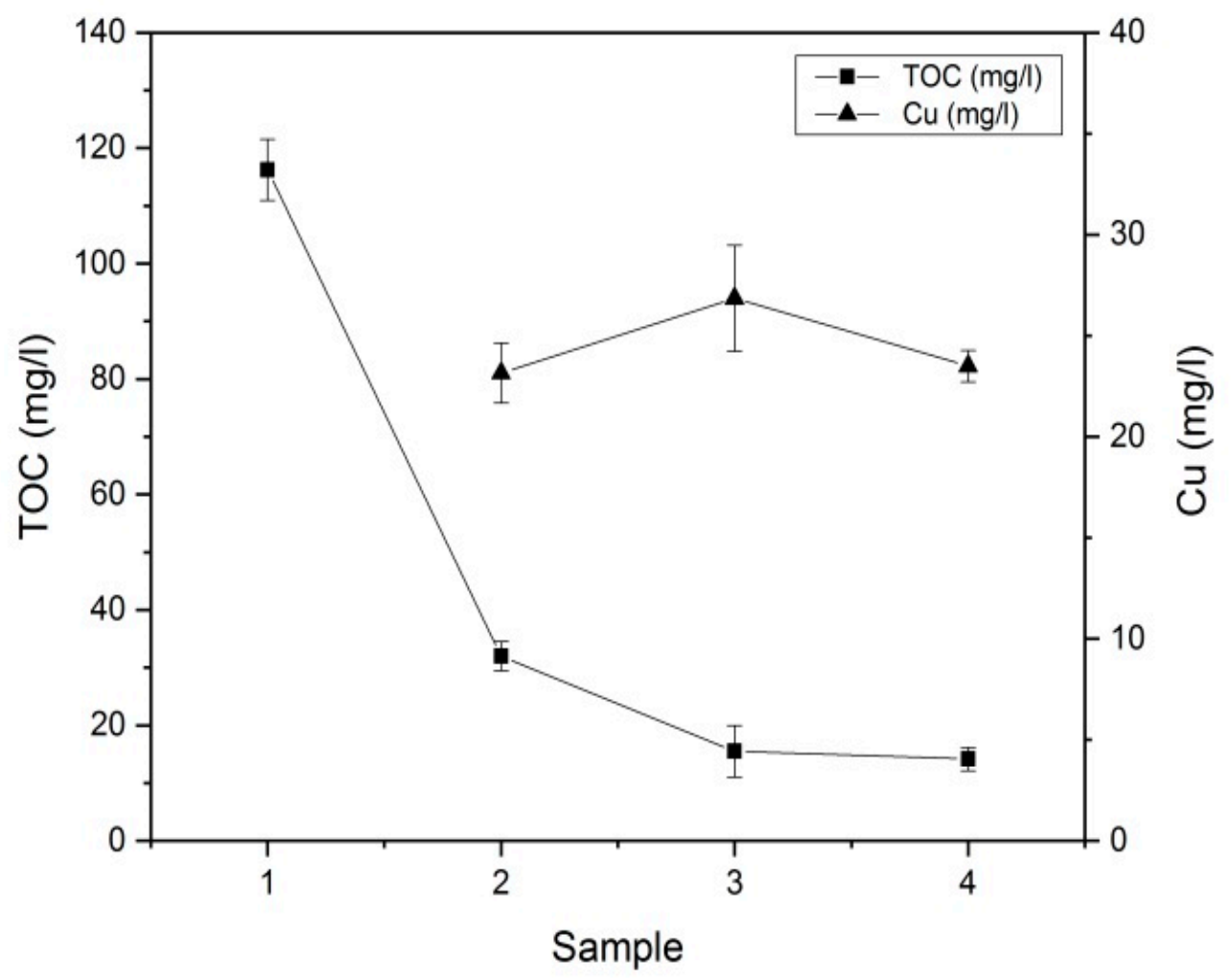

Figure 6. Change in TOC and $\mathrm{Cu}^{2+}$ depending on the sample (Sample 1: $0.1 \% \mathrm{Al}_{2}\left(\mathrm{SO}_{4}\right)_{3}$ without $\mathrm{Cu}^{2+}$, Sample 2: $0.1 \% \mathrm{Al}_{2}\left(\mathrm{SO}_{4}\right)_{3}$ with $\mathrm{Cu}^{2+}$, Sample 3: $0.3 \% \mathrm{Al}_{2}\left(\mathrm{SO}_{4}\right)_{3}$ with $\mathrm{Cu}^{2+}$, Sample 4: $0.5 \% \mathrm{Al}_{2}\left(\mathrm{SO}_{4}\right)_{3}$ with $\mathrm{Cu}^{2+}$ ).

Each effect of the factors is explained using regression analysis and expressed in Table 2. As discussed above, decreasing TOC indicates that Alg-Rh complexes are combined with heavy metals, resulting in carbon being decreased in the samples. However, aluminum and sulfate ions are evaluated to have relatively little influence. This is considered because the Alg-Rh complexes are also combined with copper ions. 
Table 2. Regression analysis.

\begin{tabular}{cccc}
\hline Specification & TOC & $\mathbf{S O}_{4}{ }^{2-}$ & $\mathbf{A l}^{3+}$ \\
\hline $\mathrm{R}^{2}$ & 0.948 & 0.840 & 0.859 \\
$p$ value & 0.004 & 0.094 & 0.089 \\
F value & 0.026 & 0.262 & 0.245
\end{tabular}

Note: $\mathrm{R}^{2}$ coefficient of determination; $p<0.05$, indicating significant difference; $\mathrm{F}$ value, indicating the degree of statistical confidence.

\subsection{Efficiency of Heavy Metal Removal}

Herein, the efficiency of $\mathrm{Cu}$ removal would be discussed as one of the important objectives to obtain clean water (Figure 7). As explained above, the $\mathrm{Cu}^{2+}$ contents were not extremely changed with the change in $\mathrm{Al}_{2}\left(\mathrm{SO}_{4}\right)_{3}$ concentrations. The efficiency of $\mathrm{Cu}$ removal is also depicted similarly, respectively at 78.7, 75.3 and $76.5 \%$. Most of the removed $\mathrm{Cu}^{2+}$ concentrations would be considered to react with Alg-Rh solutions and $\mathrm{Al}_{2}\left(\mathrm{SO}_{4}\right)_{3}$. They are considered to be quite high amounts and deserve to be researched more in detail. Furthermore, a higher concentration of $\mathrm{Cu}^{2+}$ might have an impact on coagulation, and it also improves the efficiency to increase the Cu removal. As discussed above, other heavy metals with similar ionic states might be expected to have a similar role to that of $\mathrm{Cu}^{2+}$. There were not observed to be a dramatic effect depending on the concentration of aluminum sulfate. However, both the concentration and kind of heavy metals would affect the degree of heavy metal removal. Further studies about these factors would be needed.

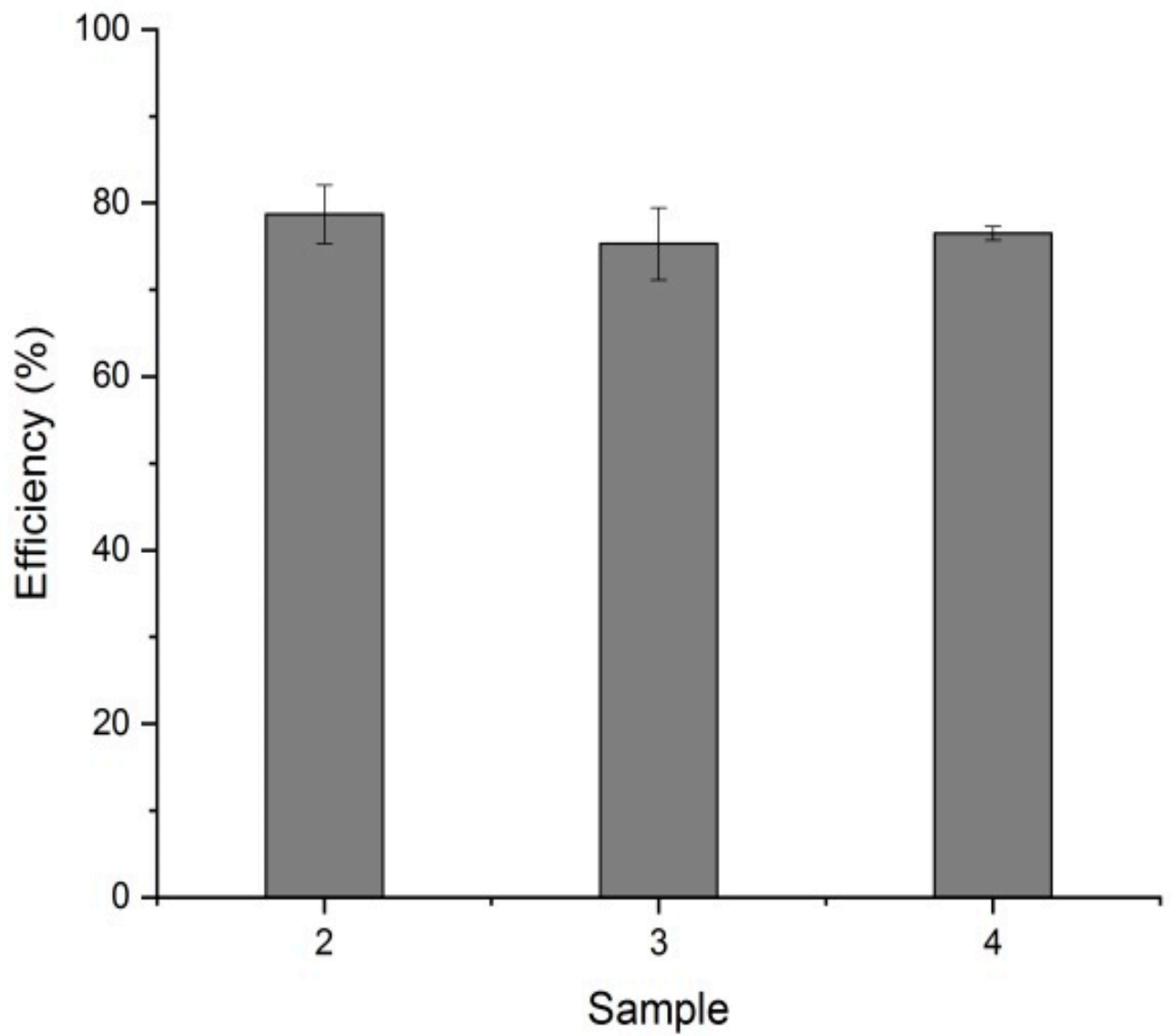

Figure 7. Removal efficiency change of $\mathrm{Cu}^{2+}$ in the liquid phase depending on the sample's conditions (Sample 2: $0.1 \% \mathrm{Al}_{2}\left(\mathrm{SO}_{4}\right)_{3}$ with $\mathrm{Cu}^{2+}$, Sample 3: $0.3 \%\left(\mathrm{Al}_{2}\left(\mathrm{SO}_{4}\right)_{3}\right)$ with $\mathrm{Cu}^{2+}$, Sample 4: $0.5 \% \mathrm{Al}_{2}\left(\mathrm{SO}_{4}\right)_{3}$ with $\mathrm{Cu}^{2+}$ ). 


\section{Conclusions}

In this research, we studied Alg- $\mathrm{Rh}$ solutions reacting with $\mathrm{Al}_{2}\left(\mathrm{SO}_{4}\right)_{3}$ to remove $\mathrm{Cu}^{2+}$ by coagulation. The total volume of the liquid phase separated from the solid phase has been increased with the existence of $\mathrm{Cu}^{2+}$ and the concentration of $\mathrm{Al}_{2}\left(\mathrm{SO}_{4}\right)_{3}$. $\mathrm{Al}^{3+}$ and $\mathrm{SO}_{4}{ }^{2-}$ have been also increased with the concentration of $\mathrm{Al}_{2}\left(\mathrm{SO}_{4}\right)_{3}$. Furthermore, the efficiency of the $\mathrm{Cu}^{2+}$ removal constantly stayed above $75.0 \%$. Therefore, this indicates that the existence of $\mathrm{Cu}^{2+}$ has an impact on tighter coagulation with $\mathrm{Al}_{2}\left(\mathrm{SO}_{4}\right)_{3}$ but $\mathrm{Al}_{2}\left(\mathrm{SO}_{4}\right)_{3}$ does not extremely affect removing $\mathrm{Cu}^{2+}$. This knowledge is worth applying to other heavy metals. More detailed studies should be researched about the effect of $\mathrm{Cu}^{2+}$ and Alg-Rh concentration changes.

Author Contributions: Conceptualization, A.L. and K.K.; investigation, A.L.; data analysis, A.L. and K.K.; methodology, A.L. and K.K.; writing—original draft, A.L.; writing-review and editing, A.L. and K.K.; project administration, A.L.; supervision, K.K. All authors have read and agreed to the published version of the manuscript.

Funding: This work was supported by the Korea Institute of Ocean Science and Technology under Grant (PE99723 and PE99823), Republic of Korea.

Conflicts of Interest: The authors declare no conflict of interest.

\section{References}

1. Sivakami, M.S.; Gomathi, T.; Venkatesan, J.; Jeong, H.; Kim, S.; Sudha, P.N. Preparation and characterization of nano chitosan for treatment wastewaters. Int. J. Biol. Macromol. 2013, 57, 204-212. [CrossRef]

2. Qasim, M.; Badrelzaman, M.; Darwish, N.N.; Darwish, N.A.; Hidal, N. Reverse osmosis desalination: A state-of-the-art review. Desalination 2019, 459, 59-104. [CrossRef]

3. Yoon, J.; Do, V.; Pham, V.; Han, J. Return flow ion concentration polarization desalination: A new way to enhance electromembrane desalination. Water Res. 2019, 159, 501-510. [CrossRef]

4. Yan, Z.; Pan, J.; Gao, F.; An, Z.; Liu, H.; Huang, Y.; Wang, X. Seawater quality criteria derivation and ecological risk assessment for oil pollution in China. Mar. Pollut. Bull. 2019, 142, 25-30. [CrossRef] [PubMed]

5. Quesada, H.; Baptista, A.; Cusioli, L.; Seibert, D.; Bezerra, C.; Bergamasco, R. Surface water pollution by pharmaceuticals and an alternative ofremoval by low-cost adsorbents: A review. Chemosphere 2019, 222, 766-780. [CrossRef]

6. Chu, Z.; Fan, X.; Wang, W.; Huang, W. Quantitative evaluation of heavy metals' pollution hazards andestimation of heavy metals' environmental costs in leachate during foodwaste composting. Waste Manag. 2019, 84, 119-128. [CrossRef]

7. Zhang, L.; Zhu, G.; Ge, X.; Xu, G.; Guan, Y. Novel insights into heavy metal pollution of farmland based on reactiveheavy metals (RHMs): Pollution characteristics, predictive models, andquantitative source apportionment. J. Hazard. Mater. 2018, 360, 32-42. [CrossRef]

8. Zhang, Y.; Li, S.; Lai, Y.; Wang, L.; Wang, F.; Chen, Z. Predicting future contents of soil heavy metals and related health risks by combining the models of source apportionment, soil metal accumulation and industrial economic theory. Ecotoxicol. Environ. Saf. 2019, 171, 211-221. [CrossRef]

9. Rai, P.; Lee, S.; Zhang, M.; Tsang, Y.; Kim, K. Heavy metals in food crops: Health risks, fate, mechanisms, and management. Environ. Int. 2019, 125, 365-385. [CrossRef]

10. Carolin, C.F.; Kumar, P.S.; Saravanan, A.; Joshiba, G.; Naushad, M. Efficient techniques for the removal of toxic heavy metals from aquaticenvironment: A review. J. Environ. Chem. Eng. 2017, 5, 2782-2799. [CrossRef]

11. Peterson, B.; Tietböhl, T.; Marqueze, A. Interference of heavy metals present in the water of the Lagoa Tramandai/RS on the carbohydrate metabolism of the GURI Sea Catfish (G. genidens) and Bay whiff (C. spilopterus). Comp. Biochem. Physiol. Part C 2019, 219, 42-49. [CrossRef]

12. Houri, T.; Khairallah, Y.; Zahab, A.; Osta, B.; Romanos, D.; Haddad, G. Heavy Metals Accumulation Effects on the Photosynthetic Performance of Geophytes in Mediterranean Reserve. J. King Saud Univ. 2019. [CrossRef]

13. Meena, R.; Kannah, Y.; Sindhu, J.; Ragavi, J.; Kumar, G.; Gunasekaran, M.; Rajesh, J. Trends and resource recovery in biological wastewater treatment system. Bioresour. Technol. Rep. 2019, 7, 100235. [CrossRef]

14. Bora, A.; Dutta, R. Removal of metals $(\mathrm{Pb}, \mathrm{Cd}, \mathrm{Cu}, \mathrm{Cr}, \mathrm{Ni}$, and $\mathrm{Co}$ ) from drinking water by oxidation-coagulation-absorption at optimized pH. J. Water Process Eng. 2019, 31, 100839. [CrossRef] 
15. Yun, Y.; Lee, E.; Kim, K.; Han, J. Sulfate reducing bacteria-based wastewater treatment system integrated with sulfide fuel cell for simultaneous wastewater treatment and electricity generation. Chemosphere 2019. [CrossRef]

16. Kazi, C.; Yamamoto, O. Effectiveness of the sodium alginate as surgical sealant materials. Wound Med. 2019, 24, 18-23. [CrossRef]

17. Bang, S.; Choi, J.; Cho, K.; Chung, C.; Kang, H.; Hong, S. Simultaneous reduction of copper and toxicity in semiconductor wastewater using protonated alginate beads. Chem. Eng. J. 2016, 288, 525-531. [CrossRef]

18. Wang, S.; Mulligan, C.N. Rhamnolipid biosurfactant-enhanced soil flushing for the removal of arsenic and heavy metals from mine tailings. Process Biochem. 2009, 44, 296-301. [CrossRef]

19. Di Palma, L.; Petrucci, E.; Pietrangeli, B. Environmental effects of using chelating agents in polluted sediment remediation. Bull. Environ. Contam. Toxicol. 2015, 94, 340-344. [CrossRef]

20. Mao, X.; Jiang, R.; Xiao, W.; Yu, J. Use of surfactants for the remediation of contaminated soils: A review. J. Hazard. Mater. 2015, 285, 419-435. [CrossRef]

21. Chen, W.; Qu, Y.; Xu, Z.; He, F.; Chen, Z.; Huang, S.; Li, Y. Heavy metal $(\mathrm{Cu}, \mathrm{Cd}, \mathrm{Pb}, \mathrm{Cr})$ washing from river sediment using biosurfactant rhamnolipid. Environ. Sci. Pollut. Res. 2017, 24, 16344-16350. [CrossRef] [PubMed]

22. Kim, G.; Seo, Y.; Kim, I.; Han, J. Co-production of biodiesel and alginate from Laminaria japonica. Sci. Total Environ. 2019, 673, 750-755. [CrossRef] [PubMed]

23. Zeftawy, M.A.; Mulligan, C. Use of rhamnolipid to remove heavy metals from wastewater by micellar-enhanced ultrafiltration (MEUF). Sep. Purif. Technol. 2011, 77, 120-127. [CrossRef]

24. Kaygusuz, H.; Uzaşçı, S.; Erim, F.B. Removal of Fluoride from Aqueous Solution Using Aluminum Alginate Beads. Clean-Soil Air Water 2014, 43, 724-730. [CrossRef]

25. Wang, M.; Yang, Q.; Zhao, X.; Wang, Z. Highly efficient removal of copper ions from water by using a novel alginate-polyethyleneimine hybrid aerogel. Int. J. Biol. Macromol. 2019, 138, 1079-1086. [CrossRef]

26. Li, Y.; Xia, B.; Zhao, Q.; Liu, F.; Zhang, P.; Du, Q.; Wang, D.; Li, D.; Wang, Z.; Zia, Y. Removal of copper ions from aqueous solution by calcium alginate immobilized kaolin. J. Environ. Sci. 2011, 23, 404-411. [CrossRef]

27. Papageorgiou, S.; Katsaros, F.; Kouvelos, E.; Nolan, J.; Deit, H.; Kanellopoulos, N. Heavy metal sorption by calcium alginate beads from Laminaria digitate. J. Hazard. Mater. B 2006, 137, 1765-1772. [CrossRef]

28. Blando, A.; Macias, M.; Cantero, D. Formation of calcium alginate gel capsules: Influence of sodium alginate and $\mathrm{CaCl} 2$ concentration on gelation kinetics. J. Biosci. Bioeng. 1999, 88, 686-689. [CrossRef]

29. He, X.; Abdoli, L.; Li, H. Participation of copper ions in formation of alginate conditioning layer: Evolved structure and regulated microbial adhesion. Colloids Surf. B Biointerfaces 2018, 162, 220-227. [CrossRef]

30. Liu, Y.; Li, Z.; Wang, J.; Zhu, P.; Zhao, J.; Zhang, C.; Guo, Y.; Jin, X. Thermal degradation and pyrolysis behavior of aluminum alginate investigated by TG-FTIR-MS and Py-GC-MS. Polym. Degrad. Stab. 2015, 118, 59-68. [CrossRef]

31. Zhou, Q.; Xiaoyan, L.; Bin, L.; Xuegang, L. Fluoride adsorption from aqueous solution by aluminum alginate particles prepared via electrostatic spinning device. Chem. Eng. J. 2014, 256, 306-315. [CrossRef]

Publisher's Note: MDPI stays neutral with regard to jurisdictional claims in published maps and institutional affiliations.

(C) 2020 by the authors. Licensee MDPI, Basel, Switzerland. This article is an open access article distributed under the terms and conditions of the Creative Commons Attribution (CC BY) license (http://creativecommons.org/licenses/by/4.0/). 